Pobrane z czasopisma Studia Iuridica Lublinensia http://studiaiuridica.umes.pl Data: 26/04/2023 14:04:03

Glosses Studia luridica Lublinensia vol. XXIX, 3, 2020 DOI: 10.17951/sil.2020.29.3.289-300

Piotr Poniatowski

Uniwersytet Marii Curie-Skłodowskiej w Lublinie, Polska ORCID: 0000-0001-9712-0663

piotr.poniatowski@umcs.pl

\title{
Glosa do postanowienia Sądu Apelacyjnego w Krakowie z dnia 29 września 2016 r. (II AKz 321/16) - w kwestii trybu ścigania przestępstw przeciwko mieniu, gdy czyn został popełniony w stosunku do mienia znacznej wartości (art. 294 § 1 k.k.)
}

Gloss to the Decision of the Court of Appeal in Kraków of 29 September 2016 (II AKz 321/16) - Concerning the Procedure for Prosecuting Offences against Property When the Act Was

Committed in Relation to Property of Significant Value (Article $294 \S 1$ of the Penal Code)

\section{STRESZCZENIE}

Glosowane postanowienie dotyczy ważnego w praktyce, a szerzej nieomawianego w doktrynie ani orzecznictwie, problemu trybu ścigania przestępstw przeciwko mieniu, gdy czyn został popełniony w stosunku do mienia znacznej wartości (art. 294 § 1 k.k.). Autor zgadza się z poglądem wyrażonym przez Sąd Apelacyjny w Krakowie, jednocześnie jednak uważa, że kwestia trybu ścigania przestępstw wskazanych w art. 294 k.k. powinna zostać wyraźnie uregulowana przez ustawodawcę.

Słowa kluczowe: przestępstwa przeciwko mieniu znacznej wartości; przestępstwo oszustwa; tryb ścigania 
Sąd Apelacyjny w Krakowie stwierdził w glosowanym postanowieniu ${ }^{1}$, co następuje:

1. ,[S]koro ściganie przestępstwa o znamionach typu podstawowego uzależnione jest od woli pokrzywdzonego, to jego wola ma decydujące znaczenie również dla ścigania sprawcy przestępstwa typu kwalifikowanego w wypadku, w którym [...] postępowanie toczy się w kwestii odpowiedzialności za przestępstwo przeciwko mieniu, tj. takie, w wypadku którego nie chodzi o ochronę dobra o charakterze osobistym".

2. „,[P]rzestępstwo z art. $286 \S 1$ k.k. w zw. z art. $294 \S 1$ k.k. popełnione na szkodę osoby najbliższej nie następuje w trybie publicznoskargowym bezwarunkowym $[\ldots]$, lecz na wniosek pokrzywdzonego $[\ldots]$ ".

\section{STAN FAKTYCZNY ROZPATRYWANEJ SPRAWY}

Postanowieniem z dnia 22 sierpnia 2016 r. (VI K 257/15) Sąd Okręgowy w Krakowie „umorzył postępowanie przeciwko R.S. oraz P.W. oskarżonym o to, że 23 września 2010 r. w L., w celu osiągnięcia korzyści majątkowej, działając wspólnie i w porozumieniu, doprowadzili A.S. do niekorzystnego rozporządzenia mieniem w postaci nieodpłatnego przekazania działki ewid. nr [...], objętej księgą wieczystą $\mathrm{nr}$ [...], o wartości $337812 \mathrm{zl}$, co stanowi mienie znacznej wartości po uprzednim wyzyskaniu jego niezdolności do należytego pojmowania przedsiębranego działania jako strony umowy udokumentowanej aktem notarialnym $\mathrm{nr}[\ldots]$, polegającego na świadomym i dobrowolnym rozporządzeniu wyżej opisanym mieniem, z uwagi na stan psychiczny pokrzywdzonego w postaci zespołu psychoorganicznego o nasileniu otępiennym - wobec braku wniosku o ściganie pochodzącego od osoby uprawnionej". Zawiadomienie o popełnieniu przestępstwa złożyła B.S. (żona pokrzywdzonego), ,przy czym nieruchomość będąca przedmiotem niekorzystnego rozporządzenia stanowiła wyłączną własność pokrzywdzonego A.S. i nie wchodziła w zakres majątku wspólnego małżonków". Jako sprawcy przestępstwa zostali wskazani w zawiadomieniu R.S. i P.W. (dzieci pokrzywdzonego z pierwszego małżeństwa). Zdaniem Sądu Okręgowego postępowanie w niniejszej sprawie należało „umorzyć z uwagi na brak wniosku o ściganie pochodzącego od A.S., jako osoby uprawnionej, skoro przedmiotowa nieruchomość nie wchodziła w zakres majątku wspólnego małżonków, stanowiąc jego wyłączną własność". Na powyższe postanowienie zażalenie w całości, na niekorzyść oskarżonych, złożył prokurator. W uzasadnieniu zażalenia podkreślił, że ,»czyn zabroniony stypizowany w art. $286 \S 1$ k.k. w zw. z art. $294 \S 1$ k.k., jako przestępstwo kwalifikowane

1 LEX nr 2123034; http://orzeczenia.ms.gov.pl/content/\$N/152000000001006_II_ AKz_000321_2016_Uz_2016-09-29_001 [dostęp: 20.02.2020]. 
w stosunku do oszustwa w typie podstawowym z art. $286 \S 1$ k.k, nie stanowi przestępstwa ściganego na wniosek, ale stanowi czyn zabroniony ścigany z urzędu «. W konsekwencji stwierdził, że brak wniosku o ściganie pochodzącego od osoby uprawnionej nie stanowi w niniejszej sprawie negatywnej przesłanki procesowej”.

Glosowanym orzeczeniem Sąd Apelacyjny w Krakowie uchylił zaskarżone postanowienie i przekazał sprawę do ponownego rozpoznania sądowi I instancji. W uzasadnieniu podniesiono, że stwierdzenie przez Sąd Okręgowy negatywnej przesłanki procesowej z art. $17 \S 1$ pkt 10 k.p.k., tj. braku wniosku o ściganie pochodzącego od osoby uprawnionej, było przedwczesne, gdyż na sądzie tym „spoczywa powinność uzyskania stanowczego oświadczenia uprawnionej osoby w kwestii wniosku o ściganie przestępstwa z art. $286 \S 1$ k.k. w zw. z art. 294 $\S 1$ k.k. popełnionego na szkodę osoby najbliższej, a możliwość złożenia wniosku o ściganie, a tym samym konwalidacji wcześniejszych etapów postępowania, aktualizuje się także na etapie postępowania sądowego, a nawet po uprawomocnieniu się orzeczenia kończącego postępowanie aż do upływu terminu przedawnienia karalności przestępstwa”.

\section{OMÓWIENIE KWESTII PRAWNEJ ROZPATRYWANEJ PRZEZ SĄD}

Zgodnie $\mathrm{z}$ art. $294 \S 1$ k.k. kto dopuszcza się przestępstwa określonego w art. 278 $\S 1$ lub 2, art. $284 \S 1$ lub 2, art. $285 \S 1$, art. $286 \S 1$, art. $287 \S 1$, art. $288 \S 1$ lub 3, lub w art. $291 \S 1$, w stosunku do mienia znacznej wartości², podlega karze pozbawienia wolności od roku do lat 10. Przepis ten nie zawiera regulacji dotyczącej trybu ścigania, co może sugerować, że kwalifikowane postaci przestępstw $\mathrm{w}$ nim wskazanych są ścigane w trybie publicznoskargowym z urzędu․ Należy jednak zauważyć, że większość z tych przestępstw w typach podstawowych jest ścigana na wniosek: czy to względnie (gdy pokrzywdzonym jest osoba najbliższa dla sprawcy - art. $278 \S 4$, art. $284 \S 4$, art. $285 \S 2$, art. $286 \S 4$, art. $287 \S 3$ k.k.), czy bezwzględnie (niezależnie od stosunku łączącego sprawcę z pokrzywdzonym - art. $288 \S 4$ k.k.).

W piśmiennictwie do kwestii trybu ścigania w kontekście art. $294 \S 1$ k.k. odniósł się szerzej B. Michalski. Autor ten zwrócił uwagę, że w przepisach określających wnioskowy tryb ścigania niektórych przestępstw wskazanych w tym przepisie zastosowano dwie odmienne techniki redakcyjne, a mianowicie: 1) ustanawiając

2 Mieniem znacznej wartości jest mienie, którego wartość w czasie popełnienia czynu zabronionego przekracza 200 tys. zł (art. $115 \S 5$ k.k.).

3 W myśl art. 9 § 1 k.p.k. organy procesowe prowadzą postępowanie i dokonują czynności z urzędu, chyba że ustawa uzależnia je od wniosku określonej osoby, instytucji lub organu albo od zezwolenia władzy. 
tryb ścigania przestępstwa na wniosek pokrzywdzonego, powołano nazwę ściganego w tym trybie przestępstwa (art. 278 § 4 k.k. - „kradzież”, art. 284 § 4 k.k. „przywłaszczenie”, art. $287 \S 3$ k.k. - „oszustwo”); 2) ustanawiając tryb ścigania przestępstwa na wniosek pokrzywdzonego, wskazano tylko przepis określający ścigany w tym trybie typ przestępstwa (art. $285 \S 2$ k.k. - „czyn określony w $§ 1$ ”, art. $286 \S 4$ k.k. - „czyn określony w § 1-3”, art. 288 § 4 k.k. - „przestępstwo określone w $\S 1$ lub 2")4. Bezsporne jest zdaniem B. Michalskiego, że w sytuacji gdy przepis określający tryb ścigania na wniosek pokrzywdzonego odwołuje się do nazwy ściganego $w$ tym trybie przestępstwa, to taki tryb ścigania dotyczy wszystkich odmian takiego przestępstwa, w jego typie podstawowym, uprzywilejowanym i kwalifikowanym ${ }^{5}$. Z takim poglądem należy się zgodzić, co uczynił także Sąd Apelacyjny w glosowanym orzeczeniu. Odnośnie natomiast do przestępstw z drugiej wskazanej grupy cytowany autor stwierdził, że nie jest sprawą przypadku odmienna redakcja dotycząca trybu ścigania na wniosek pokrzywdzonego polegająca na wyraźnym wskazaniu, że tego rodzaju tryb ścigania dotyczy wyłącznie przestępstwa określonego w konkretnym przepisie, co może oznaczać, że niewymienione w takim wypadku w przepisie określającym tryb ścigania na wniosek przestępstwo określone w przepisie przewidującym typ kwalifikowany (art. 294 § 1 lub § 2 k.k.) jest ścigane $\mathrm{z}$ urzędu, a więc w innym trybie niż odpowiadające mu przestępstwo typu podstawowego ${ }^{6}$. Sąd Apelacyjny w Krakowie słusznie taki pogląd odrzucił, wskazując, że „skoro ściganie przestępstwa o znamionach typu podstawowego uzależnione jest od woli pokrzywdzonego, to jego wola ma decydujące znaczenie również dla ścigania sprawcy przestępstwa typu kwalifikowanego w wypadku, w którym - tak jak w niniejszej sprawie - postępowanie toczy się w kwestii odpowiedzialności za przestępstwo przeciwko mieniu, tj. takie, w wypadku którego nie chodzi o ochronę dobra o charakterze osobistym". Podkreślił jednak, że koncepcji nawiązującej do dwóch różnych technik legislacyjnych zastosowanych w przepisach określających wnioskowy tryb ścigania niektórych spośród przestępstw wymienionych w art. $294 \S 1$ k.k. nie sposób odmówić atrakcyjności; nie wydaje się jednak, żeby na odmienności w językowym ujęciu przepisów określających wnioskowy tryb ścigania przestępstw wymienionych w art. $294 \S 1$ k.k. można było opierać konkluzję o odmiennym trybie ścigania niektórych spośród przestępstw wskazanych w art. $294 \S 1$ k.k. w wypadku ich kwalifikowanej odmiany.

Poszukując argumentów dla stanowiska prezentowanego przez Sąd Apelacyjny, a akceptowanego przeze mnie, należy odnieść się na początku do wzmiankowanej kwestii zastosowania przez ustawodawcę dwóch technik legislacyjnych dotyczą-

4 B. Michalski, [w:] Kodeks karny. Część szczególna, t. 2: Komentarz do artykułów 222-316, red. A. Wąsek, Warszawa 2006, s. 1138.

Ibidem.

6 Ibidem. 
cych określania wnioskowego trybu ścigania niektórych przestępstw przeciwko mieniu. Dlaczego w przypadku przestępstw z art. 285, 286 i 288 k.k. wskazano konkretne jednostki redakcyjne, a nie zastosowano po prostu nazw przestępstw, jak w przypadku kradzieży, przywłaszczenia czy oszustwa (tzw. komputerowego)? Odpowiedź jest chyba dużo prostsza, niż mogłoby się wydawać. Słowa „kradzież”, „przywłaszczenie” czy „oszustwo” stanowią tradycyjne nazwy określonych przestępstw i są od dawna powszechnie stosowane w doktrynie i orzecznictwie. Są to nazwy krótkie i dość oczywiste (nie tylko dla prawnika, lecz także dla przeciętnego człowieka bez wykształcenia prawniczego). Jak nazwać syntetycznie przestępstwo $\mathrm{z}$ art. 285 czy z art. 288 k.k.? Jest to raczej niemożliwe. $Z$ kolei w art. $286 \S 4$ k.k. nie można było użyć słowa „oszustwo”, gdyż czyn stypizowany w art. 286 § 2 k.k., choć w literaturze określa się go „oszustwem pokradzieżowym" ", oszustwem w istocie nie jest ${ }^{8}$. Należy więc stwierdzić, że odmienna redakcja przepisów statuujących tryb ścigania niektórych przestępstw przeciwko mieniu - cytując przytoczoną wypowiedź B. Michalskiego - rzeczywiście „nie jest sprawą przypadku”, jednakże nie dlatego - jak twierdzi ten autor - że ustawodawca chciał, aby były one ścigane w typach kwalifikowanych przewidzianych w art. 294 k.k. z urzędu, lecz ze wskazanych przeze mnie względów czysto językowych. Poczynione ustalenie nie rozwiązuje jednak głównego problemu. Wytłumaczenie zastosowania przez ustawodawcę takiej, a nie innej techniki legislacyjnej nie dowodzi jeszcze, że wszystkie przestępstwa przeciwko mieniu wskazane w art. $294 \S 1$ k.k., gdy mienie to miało znaczną wartość, ścigane są w takim samym trybie zarówno w typach podstawowych, jak i kwalifikowanych. Wykładnia językowa nie daje jednoznacznych rezultatów, należy więc sięgnąć po inne metody interpretacji.

Idźmy więc dalej, odnosząc się do argumentów systemowych, a konkretnie do techniki legislacyjnej ustanawiania innego niż publicznoskargowy z urzędu trybu ścigania. Analiza Kodeksu karnego pod tym względem prowadzi do stwierdzenia, że wskazanie, iż ściganie następuje na wniosek (pokrzywdzonego lub innego uprawnionego podmiotu) bądź z oskarżenia prywatnego, znajduje się w tym samym artykule, w którym stypizowane jest dane przestępstwo. W dwóch wypadkach ustawodawca zmodyfikował jednak typy czynów zabronionych ścigane na wniosek, nie wskazując przy tym trybu ścigania typów zmodyfikowanych. Chodzi

7 Zob. w szczególności: S. Łagodziński, Oszustwo pokradzieżowe, „Prokuratura i Prawo” 1998, nr 5, s. 38 i n.; A.N. Preibisz, Karnoprawna ocena żądania korzyści za zwrot bezprawnie zabranej rzeczy, „Prokuratura i Prawo” 2005, nr 5, s. 50 i n.

8 Oszustwem w rozumieniu potocznym (a więc świadomym wprowadzeniem kogoś w błąd lub wyzyskaniem czyjegoś błędu dla własnej korzyści) nie jest również przestępstwo z art. 287 k.k., jednakże ustawodawca tworząc ten typ czynu zabronionego, skorzystał z licentia poetica i nazwał go „oszustwem”. Nie musiał w tym przypadku odnosić się do dwóch różnych typów przestępstw (jak w art. $286 \S 4$ k.k.), a więc rozwiązanie przyjęte w art. $287 \S 3$ k.k. nie budzi wątpliwości interpretacyjnych. 
o omawiany art. 294 k.k. oraz art. 283 k.k. Zgodnie z tym drugim przepisem, w wypadku mniejszej wagi, sprawca czynu określonego w art. $279 \S 1$, art. 280 § 1 lub art. 281 lub 282 podlega karze pozbawienia wolności od 3 miesięcy do lat 5. W jakim trybie ścigana jest kradzież z włamaniem, którą można zakwalifikować jako wypadek mniejszej wagi, popełniona na szkodę osoby najbliższej? Odpowiedź na to pytanie jest chyba dla każdego oczywista, chociaż nie wynika ona $\mathrm{z}$ treści art. 283 k.k., lecz z wnioskowania a fortiori. Skoro kradzież z włamaniem w typie bazowym (użycie słowa ,podstawowy” byłoby niezręczne, gdyż przestępstwo to stanowi kwalifikowany typ kradzieży) ścigana jest na wniosek pokrzywdzonego, jeśli sprawca był dla niego osobą najbliższą, to typ uprzywilejowany (wypadek mniejszej wagi) tym bardziej powinien być ścigany w tym trybie. Rozumowania tego nie można jednak przenieść na grunt art. 294 k.k., gdyż określono w nim typy kwalifikowane niektórych przestępstw przeciwko mieniu. Nie oznacza to jednak, że te bardziej karygodne typy czynów zabronionych ścigane są z urzędu. Na tym etapie wykładni wiemy już, że niekoniecznie tryb ścigania musi być określony w tej samej jednostce redakcyjnej, w której stypizowano czyn zabroniony (uznaję wypadek mniejszej wagi za typ uprzywilejowany przestępstwa). Brak wskazania trybu ścigania w art. 294 k.k. stawia nas przed kolejnym rozdrożem. Wybór właściwej drogi uwarunkowany jest zastosowaniem wykładni celowościowej. Sięgnąć musimy do ratio legis wprowadzenia wnioskowego trybu ścigania odnośnie do niektórych typów przestępstw.

Krótkiego przeglądu kryteriów uzasadniających wprowadzenie trybu wnioskowego dokonał I.B. Nestoruk' ${ }^{9}$ Generalnie podkreśla się, że ratio legis takiego trybu ścigania zasadza się na ochronie interesu osoby pokrzywdzonej, która z różnych względów może nie życzyć sobie wszczynania postępowania karnego o przestępstwo, które naruszyło lub zagroziło jej dobru chronionemu prawem. Takimi względami może być ściśle osobisty (prywatny, intymny) charakter dobra prawnego (np. przestępstwo narażenia na zarażenie wirusem HIV lub chorobą - art. $161 \S 1$ i 2 k.k., stalking - art. 190a § 1 k.k., wykonanie zabiegu leczniczego bez zgody pacjenta - art. 192 § 1 k.k., a także - do 27 stycznia 2014 r. - zgwałcenie) czy też ochrona życia rodzinnego (przestępstwa względnie wnioskowe popełnione na szkodę osoby najbliższej ${ }^{10}$ ). Oprócz chęci respektowania przez ustawodawcę woli

${ }^{9}$ I.B. Nestoruk, Wnioskowy tryb ścigania przestępstw w polskim i niemieckim prawie karnym, „Ruch Prawniczy, Ekonomiczny i Socjologiczny” 2001, nr 4, s. 102-103. Zob. także: W. Wolter, Nauka o przestepstwie, Warszawa 1973, s. 39; I. Andrejew, Polskie prawo karne w zarysie, Warszawa 1989, s. 111-112; J. Grajewski, Ściganie na wniosek pokrzywdzonego w świetle projektów kodyfikacji prawa karnego, „Państwo i Prawo” 1992, z. 6, s. 57-58.

${ }^{10}$ W tym kontekście J. Grajewski (op. cit., s. 50) wskazał, że „,[p]rawo, a zwłaszcza prawo karne, jest w nader ograniczonym zakresie aktywnym regulatorem życia rodzinnego na co dzień. Powszechnie jest odczuwana potrzeba autonomiczności i intymności życia rodzinnego i ułożenia stosunków rodzinnych przede wszystkim według woli jej członków. [...] Nie dziwi więc od dawna 
samego pokrzywdzonego zwraca się również uwagę na małą wagę niektórych czynów, trudności w ściganiu niektórych przestępstw w trybie prywatnoskargowym, a także na problemy natury dowodowej, które mogłyby zaistnieć w postępowaniu wszczętym z urzędu, gdyby pokrzywdzony nie chciał współdziałać z organami ścigania i wymiaru sprawiedliwości.

Skupmy się teraz na trybie ścigania przestępstw przeciwko mieniu, gdyż art. 294 k.k. ich właśnie dotyczy. Wyżej już wskazałem, że przestępstwa wymienione $\mathrm{w}$ tym przepisie są $\mathrm{w}$ większości przypadków ścigane na wniosek wtedy, gdy pokrzywdzonym jest osoba najbliższa dla sprawcy (art. $278 \S 4$, art. $284 \S 4$, art. $285 \S 2$, art. $286 \S 4$, art. $287 \S 3$ k.k. - przestępstwa względnie wnioskowe). Jedynym bezwzględnie wnioskowym przestępstwem wskazanym w art. 294 k.k. jest przestępstwo zniszczenia, uszkodzenia lub uczynienia niezdatną do użytku cudzej rzeczy (art. $288 \S 1$ k.k.) ${ }^{11}$. U podstaw wprowadzenia wnioskowego trybu ścigania przestępstw, których typy podstawowe zostały wymienione w art. 294 $\S 1$ k.k., leży więc głównie wzgląd na ochronę życia rodzinnego (pozostawienie pokrzywdzonemu inicjatywy w zakresie wszczęcia ścigania przeciwko osobie mu najbliższej) ${ }^{12}$. Takie ratio legis odnosi się właśnie do trybu ścigania przestępstwa oszustwa, o którego popełnienie zostali oskarżeni R.S. oraz P.W. w omawianej sprawie. Jeśli chodzi o przestępstwo z art. 288 § 1 k.k., stwierdzić trzeba, że skoro ustawodawca wprowadził taki, a nie inny tryb ścigania, to uznał, iż w przypadku tego typu czynu zabronionego interes pokrzywdzonego przeważa nad interesem publicznym, jednakże nie z powodu bliskich relacji wiążących go ze sprawcą. Trudno ustalić, jakie były aksjologiczne przesłanki ustanowienia takiej regula-

podnoszony postulat, by twórcy prawa oraz organy posługujące się nim pamiętali, że przy kształtowaniu modelu stosunków rodzinnych powinno się mieć na względzie cel najważniejszy - trwałość i pomyślność rodziny”. Dodać trzeba, że prawo do ochrony życia prywatnego i rodzinnego stanowi wartość chronioną na gruncie Konstytucji RP (art. 47: „Każdy ma prawo do ochrony prawnej życia prywatnego, rodzinnego, czci i dobrego imienia oraz do decydowania o swoim życiu osobistym").

11 W świetle przedstawionych argumentów uzasadniających wprowadzenie w ustawie wnioskowego trybu ścigania dziwić może tryb ścigania przewidziany w art. $288 \S 4$ k.k. Zwracał na to uwagę J. Grajewski (op. cit., s. 56) już na etapie prac nad projektem obecnego Kodeksu karnego.

${ }_{12}$ Zatem przeciwko małżonkowi, wstępnemu, zstępnemu, rodzeństwu, powinowatemu w tej samej linii lub stopniu, osobie pozostającej w stosunku przysposobienia oraz jej małżonkowi bądź osobie pozostającej we wspólnym pożyciu (art. 115 § 11 k.k.). M. Cieślak wskazuje, że w takich wypadkach racja trybu wnioskowego zasadza się na dwóch okolicznościach: po pierwsze, ściganie z urzędu mogłoby wyrządzić dodatkową krzywdę pokrzywdzonemu (np. jeśli syn okradnie ojca, to postępowanie karne w stosunku do syna będzie często dla ojca trudniejszą sytuacją niż pogodzenie się z faktem kradzieży i bezkarnością syna); po drugie, jeśli pokrzywdzony nie czuje się w danym układzie (ze względu na stosunek łączący go ze sprawcą) szczególnie dotknięty, to problematyczna jest już sama szkoda, a co za tym idzie także społeczne niebezpieczeństwo czynu (dziś powiemy: społeczna szkodliwość), a więc odpadają społeczne racje jego ścigania na drodze karnej. Zob. M. Cieślak, O ściganiu na wniosek w obowiazującym polskim prawie, „Państwo i Prawo” 1973, z. 1, s. 61. 
cji. Zgodnie jednak z założeniem racjonalności prawodawcy ${ }^{13}$ trzeba uznać, że ustanowienie wnioskowego trybu ścigania przestępstwa $\mathrm{z}$ art. $288 \S 1$ k.k. było racjonalne aksjologicznie ${ }^{14}$.

Jak już wskazałem, w art. 294 k.k. opisano kwalifikowane typy wskazanych tam przestępstw przeciwko mieniu. Znamionami kwalifikującymi są: popełnienie przestępstwa w stosunku do mienia znacznej wartości (§ 1) oraz w stosunku do dobra o szczególnym znaczeniu dla kultury (§ 2). W związku z tym, że glosowane postanowienie dotyczy kwestii odpowiedzialności karnej za oszukańcze doprowadzenie do niekorzystnego rozporządzenia mieniem znacznej wartości (art. 286 $\S 1$ k.k. w zw. z art. 294 § 1 k.k.), odniosę się głównie do tego właśnie znamienia kwalifikującego. Należy zadać pytanie: Czy znaczna wartość mienia stanowiącego przedmiot czynności wykonawczej powoduje, że odpada przesłanka ustanowienia wnioskowego trybu ścigania przewidzianego wyraźnie dla typów podstawowych przestępstw wymienionych w art. $294 \S 1$ k.k.? Pytanie jest o tyle zasadne, że ani

13 Jest to założenie kontrfaktyczne, ale - jak trafnie zauważył L. Nowak - w toku wykładni prawa wymogu racjonalności prawodawcy nie usuwa się nigdy: interpretacja zakładająca nieracjonalność podmiotu normującego jest $\mathrm{z}$ góry odrzucana, prawnicy akceptują więc założenie o racjonalności ustawodawcy jako swój dogmat. Zob. L. Nowak, Metodologiczne kryterium demarkacji i problem statusu teologii, „Nauka” 2004, nr 3, s. 129-130.

${ }^{14}$ Można spróbować przyjąć, choć będzie to jedynie spekulacja myślowa, że bezwzględnie wnioskowy tryb ścigania wskazanego przestępstwa uzasadniony jest tym, że sprawca (ani żadna inna osoba) nie odnosi w przypadku jego popełnienia żadnej bezpośredniej korzyści, a skoro tak, to inicjatywa ścigania powinna należeć wyłącznie do pokrzywdzonego, nawet jeśli sprawca nie jest dlań osobą najbliższą, gdyż społeczna szkodliwość czynu uwydatnia się głównie w szkodzie poniesionej przez ten podmiot. Warto zauważyć, że zróżnicowanie trybu ścigania przestępstw przeciwko mieniu istniało zarówno w Kodeksie karnym z 1932 r., jak i w Kodeksie karnym z 1969 r. Art. 263 § k.k. z 1932 r. szedł o tyle inną drogą niż jego następcy (art. 212 § 3 k.k. z 1969 r. oraz art. 288 § 4 k.k. z 1997 r.), że przewidywał dla przestępstwa uszkodzenia albo uczynienia niezdatnym do użytku cudzego mienia tryb prywatnoskargowy (jeśli czyn sprawcy nie naruszył interesu publicznego). Takie rozwiązanie uzasadniano tym, że jeśli sprawca spowoduje stosunkowo nieznaczną szkodę, to „nie tylko interes publiczny nie jest narażony, ale nawet osoba pokrzywdzona może przedkładać zaniechanie ścigania ponad problematyczne korzyści postępowania sądowego" (Komisja Kodyfikacyjna Rzeczypospolitej Polskiej, Sekcja Prawa Karnego, Projekt Kodeksu karnego. Uzasadnienie części szczególnej, t. 5, z. 4, Warszawa 1930, s. 225). M. Cieślak (op. cit., s. 62) zaliczył omawiany typ czynu zabronionego do „bagatelnych przestępstw wnioskowych”, które cechują się stosunkowo niewielkim stopniem społecznego niebezpieczeństwa (społecznej szkodliwości), i wskazał, że powód zaliczenia go do przestępstw wnioskowych (to pokrzywdzony powinien decydować, czy czuje się danym czynem dotknięty do tego stopnia, że celowe jest ściganie karne) uzasadnia raczej wprowadzenie prywatnoskargowego trybu ścigania, co prowadzi do wniosku, że przyjęcie przez ustawodawcę ścigania na wniosek nastąpiło przez pomyłkę. Generalnie autor ten stwierdził, że społeczne racje ustanowienia ścigania omawianego przestępstwa na wniosek pokrzywdzonego nie są całkiem jasne (ibidem). Do poglądu M. Cieślaka można mieć jedno zastrzeżenie. Przestępstwo zniszczenia, uszkodzenia lub uczynienia niezdatną do użytku cudzej rzeczy nie musi być in concreto błahe, a in abstracto nie jest bardziej bagatelne niż np. kradzież zwykła (o czym przekonuje zagrożenie karne przewidziane zarówno w k.k. z 1969 r., jak i w obowiązującym k.k.). 
językowa, ani systemowa wykładnia przepisów wchodzących w grę nie daje jednoznacznej odpowiedzi w kwestii sposobu ścigania kwalifikowanych typów czynów zabronionych z art. 294 § 1 k.k., w związku z czym sięgnąc trzeba do wykładni celowościowej, pamiętając przy tym, że przyjęcie ścigania z urzędu byłoby niekorzystne dla sprawcy przestępstwa (ściganie niezależnie od inicjatywy pokrzywdzonego). Wydaje się, że jeśli ustawodawca uznał, że w przypadku niektórych przestępstw przeciwko mieniu interes pokrzywdzonego przeważa nad interesem publicznym na tyle, że to ta osoba powinna decydować, czy sprawca powinien być ścigany, to wartość mienia nie powinna mieć znaczenia w kontekście trybu ścigania. Ma to szczególne aksjologiczne uzasadnienie w przypadku przestępstw ściganych co do zasady z urzędu, lecz w sytuacji, gdy sprawcą jest osoba najbliższa sprawcy - ściganych na wniosek pokrzywdzonego ${ }^{15}$. Mniej oczywista jest sytuacja w przypadku przestępstwa $\mathrm{z}$ art. $288 \S 1$ k.k., jednakże - jak wyżej stwierdziłem - musimy założyć, że ustawodawca miał racjonalne powody do wprowadzenia bezwzględnie wnioskowego trybu ścigania tego typu czynu zabronionego, w związku z czym tryb ten powinien być ,,przejęty” $z$ typu podstawowego przez typ kwalifikowany ${ }^{16}$.

O tym, że znaczna wartość mienia, a nawet użycie przemocy lub groźby natychmiastowego jej użycia bądź doprowadzenie człowieka do stanu nieprzytomności lub bezbronności, a więc okoliczności, które bardziej zwiększają społeczną szkodliwość czynu in abstracto niż znaczna wartość mienia czy szczególne znaczenie dobra dla kultury, nie wyłączają zasadności przyjęcia wnioskowego trybu ścigania, przekonuje lektura art. 289 k.k. ${ }^{17}$ Przestępstwo stypizowane w tym przepisie (zabór cudzego pojazdu mechanicznego w celu krótkotrwałego użycia) jest w myśl art. 289 § 5 k.k.

15 W tym kontekście trafnie wskazał Sąd Apelacyjny w Krakowie (II AKz 321/16), że „[z]ważyć tu należy na przedstawioną powyżej ratio wnioskowego trybu ścigania przestępstw przeciwko mieniu popełnionych na szkodę osoby najbliższej, którą jest wzgląd na gwarancję ochronną życia rodzinnego pokrzywdzonego zakorzenioną w art. 47 Konstytucji RP. Uwzględnić nadto trzeba konstytucyjną zasadę równości wobec prawa (art. 32 ust. 1 Konstytucji RP), z której wynika nakaz takiej samej lub podobnej ochrony dóbr prawnych w sytuacjach takich samych lub podobnych ze względu na cechę prawnie relewantną".

${ }^{16}$ M. Kulik wskazuje, że przestępstwo opisane w art. $288 \S 1$ k.k. jest ścigane na wniosek także w typach kwalifikowanych w związku z art. 294 § 1 i 2 k.k. Zob. M. Kulik, [w:] Kodeks karny. Komentarz, red. M. Mozgawa, Warszawa 2019, s. 954.

${ }^{17}$ Wniosek o takiej właśnie hierarchii okoliczności obciążających wyciągnąłem z porównania sankcji określonych w art. 289 § 2 k.k. (mienie znacznej wartości - kara pozbawienia wolności od 6 miesięcy do lat 8 ) i art. $289 \S 3$ k.k. (użycie przemocy lub groźby natychmiastowego jej użycia albo doprowadzenie człowieka do stanu nieprzytomności lub bezbronności - kara pozbawienia wolności od roku do lat 10). Taki sam wniosek płynie z porównania sankcji za typy kwalifikowane kradzieży, które zostały określone w art. $280 \S 1$ i art. 294 k.k. Rozbój, a więc kradzież z użyciem przemocy wobec osoby lub groźby natychmiastowego jej użycia albo kradzież połączona z doprowadzeniem człowieka do stanu nieprzytomności lub bezbronności, zagrożony jest karą pozbawienia wolności od lat 2 do 12. Natomiast kradzież rzeczy o znacznej wartości lub o szczególnym znaczeniu dla kultury pociąga za sobą karę pozbawienia wolności od roku do lat 10. 
ścigane na wniosek, jeśli zostało popełnione na szkodę osoby najbliższej, zarówno w typie podstawowym (art. $289 \S 1$ k.k.), jak i w typach kwalifikowanych (art. 289 $\S 2$ i 3 k.k.). Ustawodawca uznał więc, że ochrona życia rodzinnego jest ważniejsza od interesu państwa wyrażającego się w ściganiu z urzędu tego przestępstwa, nawet jeśli istnieją okoliczności zwiększające stopień społecznej szkodliwości czynu. Zauważmy, że zagrożenie karne przewidziane w art. 289 § 3 k.k. jest takie samo, jak określone w art. 294 § 1 i 2 k.k. Z tego płynie wniosek o tożsamym (albo bardzo zbliżonym) stopniu karygodności (ujmowanej abstrakcyjnie) typów przestępstw opisanych w tych przepisach. Skoro więc w przypadku kwalifikowanych typów przestępstwa zaboru pojazdu mechanicznego w celu krótkotrwałego użycia nie odpada przesłanka uzasadniająca ustanowienie wnioskowego trybu ścigania, to racjonalne zdaje się uznanie, że również w przypadku typów czynów zabronionych wskazanych w art. 294 k.k. należy przyjąć tryb ścigania wyraźnie przewidziany przez ustawę dla typów bazowych.

Przedstawiona interpretacja może budzić wątpliwości na gruncie art. 294 $\S 2$ k.k., gdyż szczególne znaczenie mienia dla kultury mogłoby przeważać szalę w kontekście trybu ścigania $-\mathrm{z}$ wnioskowego na bezwarunkowo publicznoskargowy ${ }^{18}$. Sąd Apelacyjny zauważył ten problem, jednakże z uwagi na to, że sprawa nie dotyczyła art. 294 § 2 k.k., uznał, iż nie musi się do niego ustosunkowywać. Również ja nie chcę rozwijać tego tematu. Czuję się jednak w obowiązku zasygnalizowania przynajmniej głównej trudności, która się tu pojawia. Trzeba zadać pytanie: Czy przestępstwa stypizowane w jednym artykule, za popełnienie których przewidziane są takie same kary, mogą różnić się trybem ścigania w sytuacji, gdy za wyborem w praktyce określonego trybu przemawiają nie tyle uchwytne przesłanki językowe lub systemowe, lecz abstrakcyjne względy celowościowe? ${ }^{19}$ Konieczna jest tu, jak się zdaje, interwencja ustawodawcy przecinająca wskazane wątpliwości ${ }^{20}$.

Podsumowując, pogląd wyrażony w glosowanym postanowieniu w zasadzie zasługuje na akceptację. Dlatego „w zasadzie”, gdyż generalizujące stwierdzenie, że ,[s]koro ściganie przestępstwa o znamionach typu podstawowego uzależnione

${ }_{18}$ Zob. B. Michalski, op. cit., s. 1139.

${ }_{19}$ Pytanie to zostawiam bez odpowiedzi, licząc, że Czytelnik podejmie wysiłek intelektualny i postara się na nie odpowiedzieć.

${ }^{20}$ Niestety, problemu nie rozwiązuje nowelizacja art. 294 k.k. przewidziana ustawą z dnia 13 czerwca 2019 r. o zmianie ustawy - Kodeks karny oraz niektórych innych ustaw (http://orka. sejm.gov.pl/opinie8.nsf/nazwa/3451_u/\$file/3451_u.pdf, dostęp: 20.02.2020). Należy wskazać, że Prezydent RP wystąpił do Trybunału Konstytucyjnego z wnioskiem w sprawie zgodności tej ustawy z Konstytucją RP. Zmiana sprowadza się do dodania nowych typów kwalifikowanych, nie odnosi się jednak do trybu ścigania tych przestępstw. Jest to szczególnie problematyczne, gdyż nowe typy zmodyfikowane przestępstw przeciwko mieniu stanowią zbrodnie (zagrożone karą pozbawienia wolności od 3 do 20 lat albo od 5 do 25 lat). Pojawi się więc kolejny niejasny przepis zmuszający do ocennego, a więc zależącego od osoby stosującej prawo, ważenia wartości. 
jest od woli pokrzywdzonego, to jego wola ma decydujące znaczenie również dla ścigania sprawcy przestępstwa typu kwalifikowanego w wypadku, w którym [...] postępowanie toczy się w kwestii odpowiedzialności za przestępstwo przeciwko mieniu", może rodzić wątpliwości w kontekście kwalifikowanego typu przestępstw przeciwko mieniu opisanego w art. $294 \S 2$ k.k. Można bowiem w odniesieniu do tego przepisu argumentować, że skoro sprawca dopuścił się przestępstwa w stosunku do dobra o szczególnym znaczeniu dla kultury, a więc doszło do naruszenia wartości ponadindywidualnej, należnej nie tylko pokrzywdzonemu, lecz także społeczeństwu albo nawet ludzkości, to ściganie nie powinno być uzależnione wyłącznie od woli pokrzywdzonego ${ }^{21}$. Sprawa rozpatrywana przez Sąd Apelacyjny w Krakowie dotyczyła jednak art. $286 \S 1$ k.k. w zw. z art. 294 § 1 k.k., dlatego rozstrzygnięcie sądu oraz tezę odnoszącą się konkretnie do tego drugiego przepisu należy uznać za w pełni prawidłowe. De lege ferenda postulować jednak trzeba jednoznaczne uregulowanie kwestii trybu ścigania przestępstw stypizowanych w art. 294 k.k. Ingerencja ustawodawcy rozwiałaby wątpliwości, które piętrzą się na gruncie obecnego brzmienia tego przepisu.

\section{BIBLIOGRAFIA}

\section{Literatura}

Andrejew I., Polskie prawo karne w zarysie, Warszawa 1989.

Cieślak M., O ściganiu na wniosek w obowiazującym polskim prawie, „Państwo i Prawo” 1973, z. 1.

Grajewski J., Ściganie na wniosek pokrzywdzonego w świetle projektów kodyfikacji prawa karnego, „Państwo i Prawo” 1992, z. 6.

Komisja Kodyfikacyjna Rzeczypospolitej Polskiej, Sekcja Prawa Karnego, Projekt Kodeksu karnego. Uzasadnienie części szczególnej, t. 5, z. 4, Warszawa 1930.

Kulik M., [w:] Kodeks karny. Komentarz, red. M. Mozgawa, Warszawa 2019.

Łagodziński S., Oszustwo pokradzieżowe, „Prokuratura i Prawo” 1998, nr 5.

Michalski B., [w:] Kodeks karny. Część szczególna, t. 2: Komentarz do artykułów 222-316, red. A. Wąsek, Warszawa 2006.

Nestoruk I.B., Wnioskowy tryb ścigania przestęstw w polskim i niemieckim prawie karnym, „Ruch Prawniczy, Ekonomiczny i Socjologiczny" 2001, nr 4.

Nowak L., Metodologiczne kryterium demarkacji i problem statusu teologii, „Nauka” 2004, nr 3.

Preibisz A.N., Karnoprawna ocena żądania korzyści za zwrot bezprawnie zabranej rzeczy, „Prokuratura i Prawo" 2005, nr 5.

Wolter W., Nauka o przestępstwie, Warszawa 1973.

${ }^{21}$ Inaczej byłoby, gdyby przestępstwo z art. 288 § 1 k.k. ścigane było z oskarżenia prywatnego. Wtedy możliwa byłaby ingerencja prokuratora na zasadzie art. $60 \S 1$ k.p.k. 
Pobrane z czasopisma Studia Iuridica Lublinensia http://studiaiuridica.umes.pl Data: 26/04/2023 14:04:03

\section{Orzecznictwo}

Postanowienie SA w Krakowie z dnia 29 września 2016 r., II AKz 321/16, LEX nr 2123034; http:// orzeczenia.ms.gov.pl/content/\$N/152000000001006_II_AKz_000321_2016_Uz_2016-0929_001 [dostęp: 20.02.2020].

\section{SUMMARY}

The commented decision concerns an important in practice, and not wider discussed in the doctrine or jurisprudence, problem of the procedure for prosecuting crimes against property, when the act was committed in relation to property of significant value (Article $294 \S 1$ of the Penal Code). The author agrees with the view expressed by the Court of Appeal in Kraków, however, at the same time, he believes that the issue of the mode of prosecution of the crimes mentioned in Article 294 of the Penal Code should be clearly regulated by the legislator.

Keywords: offences against property of significant value; offence of fraud; procedure for prosecuting 